\title{
The Effect of Corporate Governance on Profitability, Capital Structure and Corporate Value
}

\author{
Rolens E.H. Riwu Manu \\ Student of Doctoral Program of Business Administration, Faculty of Administrative Science, \\ Brawijaya University, Jalan M.T. Haryono No. 163 Malang, East Java - Indonesia, Postal Code 65145 \\ Taher Alhabsji Sri Mangesti Rahayu Nila Firdausi Nuzula \\ Department of Business Administration, Faculty of Administrative Science, Brawijaya University, \\ Jalan M.T. Haryono No. 163 Malang, East Java - Indonesia, Postal Code 65145
}

\begin{abstract}
This study is motivated by theoretical inconsistencies that underlie agency relations, within the corporate governance framework to increase profitability, optimal capital structure, and corporate value. The results of previous researchers' research are conflicting about the effect between variables. The originality of this study lies in providing empirical evidence of the effect of corporate governance, profitability, capital structure, on corporate value. This research is considered important to be carried out to study corporate governance within the framework of agency theory capable of directing management to make managerial decisions that minimize agency problems and improve the welfare of shareholders. This study focuses on empirical testing of the theory through testing the effect between the variables of Corporate Governance, Profitability, Capital Structure, and Corporate Value. This research was conducted in Indonesia with observation objects covering all Basic Industry Manufacture companies listed on the Indonesia Stock Exchange, the observation period from 2012 to 2017 . The population was 84 companies and a sample of 25 companies. The sampling method is purposive sampling. The data analysis technique uses statistical procedures to test hypotheses with the Generalized Structured Component Analysis (GSCA) software. The findings of this study are corporate governance has a positive and significant effect on profitability, capital structure and corporate value. Profitability has a positive effect on the capital structure and corporate value. Capital structure has a positive and significant effect on corporate value. This study concludes that good corporate governance will maintain an optimal capital structure that is able to increase profitability and Corporate value. Corporate management can use these variables to predict the Corporate's future.
\end{abstract}

Keywords: Corporate Governance, Profitability, Capital Structure, Corporate Value

DOI: $10.7176 /$ RJFA/10-8-20

Publication date: April $30^{\text {th }} 2019$

\section{Introduction}

The Corporate was established to achieve the main objective of maximizing the welfare of the owner, through increasing the value of the Corporate (Keown et al., 2000: 2). The management of the Corporate is entrusted by the owner to manage the Corporate in the hope of gaining profits and adding to the owner's wealth. The management of the Corporate will use its own capital and debt together in funding various Corporate operational activities. In managing the Corporate to achieve maximum value, there is often a conflict of interest between Managers and Shareholders, which is often called agency problem.

Agency problems in companies affect the price of securities markets, because investors will assess the Corporate's performance through data contained in the Corporate financial report available on the stock exchange, the results of the assessment become a reference in making decisions whether the investment will be taken is right and gives benefits. Good corporate governance is needed to reduce agency problems because it is always oriented towards the goal of increasing Corporate value and aligning the interests of all parties. The purpose of implementing corporate governance is as a guide for management in controlling the Corporate to make the right decisions and in favor of the interests of the owners and all stakeholders. Good management will function as aligning management interests with shareholders and all stakeholders related to the Corporate. All available resources in the Corporate are fully utilized for the realization of the welfare of the shareholders and to increase the welfare of management to the fullest.

Corporate governance is based on the agency theory concept which serves to provide confidence to investors that investment in the Corporate will provide a large return for investors. Nasution and Setiawan (2007) stated that "corporate governance is a concept proposed to mediate differences in interests between managers and Corporate owners in order to improve Corporate performance through supervision or monitoring of management performance and ensuring management accountability to stakeholders based on agreed agreements".

Manager's behavior in corporate decision making is explained by agency theory (Jensen and Mecling, 1976). which explains the relationship of shareholders as principal with the manager as an agent, Eisendhart (1989) suggests there are three assumptions underlying the agency theory, namely: (1). Humans have a selfish nature and 
have rational limitations and do not like risk. (2). In organizations there are conflicts between members and there is information asymmetry between members. (3). Information is a commodity that has economic value so it is traded. Based on these assumptions, the manager has the opportunity to make deviations.

The implementation of Corporate Governance is beneficial for the sustainable growth of the Corporate in order to increase the value of the Corporate. if management is able to place the Corporate has competitiveness in seizing the market share of the products produced so as to provide maximum benefits to the investment invested in the Corporate. Corporate governance practices (CG) direct management in carrying out the main tasks and functions of corporate financial management in decision making relating to (1) funding decisions, (2) investment decisions and (3) dividend decisions, (Hanafi, 2010:3-4). The three decisions are carried out simultaneously in a unity of interrelated actions (Data et al., 2017).

The effect of corporate governance on profitability is explained through the principles of corporate governance to improve, competitiveness, credibility and profitability. Improve relations between stakeholders such as investors, business partners, employees, customers and others (Todorovic, 2013). Effective corporate governance over a long period of time improves Corporate performance and benefits shareholders, through increasing Corporate performance characterized by high levels of profitability followed by high dividend distribution and increasing stock value through high capital gains.

The effect of corporate governance on capital structure is explained through the role of Corporate governance in preventing managerial opportunistic behavior as demonstrated by the decision of low-cost, profitable capital structure that is oriented towards positive Corporate growth. Corporate governance structure consisting of board size, board composition, internal audit committee, and external audit committee effect $\mathrm{s}$ the capital structure as measured by indicators of the ratio of liabilities to total assets, the ratio of total liabilities to total equity and the ratio of total long-term liabilities to total equity. The corporate governance mechanism will direct management to make capital structure decisions that have an impact on increasing the value of the Corporate.

The effect of corporate governance on corporate value is explained by Rezaee (2007) that corporate governance is a mechanism to adjust management's interests with shareholders. Especially the role of Corporate governance in reducing agency costs and creating long-term value for shareholders with a focus on the responsibility of monitoring the board of directors and senior executive management functions.

The effect of profitability on capital structure is explained by Pecking order theory (Myers and Majluf, 1984) that when a Corporate needs capital, first, use internal funds, then debt, and finally issue new shares. Myers and Majluf (1984) state that companies that have high profitability do not depend on external funding to finance a Corporate's growth, because profitability has a negative correlation with the level of debt. If the Corporate issues new shares in the condition of information asymmetry, it will cause a decrease in stock prices, which will cause equity agency costs, thus issuing new shares is the last choice in certain situations. The results of Anake et al (2014) study found that profitability has a negative and significant effect on capital structure.

Profitability affects the value of the Corporate, because profitability is a measure of Corporate performance as measured by the profits generated. Companies that succeed in gaining ever-increasing profits indicate that the Corporate has a good performance, thus creating positive responses from investors and encouraging a rise in the Corporate's stock price. Companies with high profitability show that the Corporate manages the Corporate's wealth effectively and efficiently.

The originality of this study lies in providing empirical evidence of the effect of corporate governance variables on capital structure, profitability, and Corporate value. Motivate researchers to conduct research to reexamine arguments that state corporate governance affects, profitability, capital structure, and Corporate value. This research is considered important to do, starting from the idea that corporate governance that involves a number of board of commissioners, independent board of commissioners, representative audit committees within the framework of theoretical agencies is able to direct management to make managerial decisions that minimize agency problems.

\subsection{Research Questions}

Based on the theoretical description and previous empirical research, identification of research variables and research objectives, the formulation of the problem from this study are:

1) Does corporate governance have a significant effect on profitability?

2) Does corporate governance have a significant effect on the capital structure?

3) Does corporate governance have a significant effect on Corporate value?

4) Does profitability have a significant effect on capital structure?

5) Does profitability have a significant effect on Corporate value?

6) Does the capital structure have a significant effect on Corporate value?

\subsection{Research Objectives}

1) Test and explain corporate governance effect on profitability. 
2) Test and explain corporate governance effect on capital structure.

3) Test and explain corporate governance effect on Corporate value.

4) Test and explain the profitability of the effect on the capital structure.

5) Test and explain the profitability of the effect on the value of the Corporate.

6) Test and explain the capital structure effect on Corporate value.

\section{Literature Review}

\subsection{The Effects of Corporate Governance On Profitability}

The principles of good corporate governance can improve profitability, improve competitiveness, credibility and improve relations between key stakeholders such as investors, business partners, employees, customers, and others (Todorovic, 2013). Research by Mathur and Gill (2011), Adi et al. (2013), Yulianto (2014), Yemane (2015) found that Corporate Governance has a significant and positive effect on Corporate value, meaning that improvement (improvement) in corporate governance will increase profitability. In contrast to the findings of Coleman and Biekpe (2006), Arifin (2014) found that corporate governance has a significant and negative effect on profitability, meaning that the increase (improvement) of corporate governance will reduce profitability. The difference in empirical findings is a reason to re-examine the effect of corporate governance on profitability, with the research hypothesis as follows:

H1: Corporate governance has a significant effect on profitability.

\subsection{The Effect of Corporate Governance on Capital Structure}

Agency Theory (Jensen and Meckling, 1976) explains that corporate governance has a role in preventing managerial opportunistic behavior reflected by the Corporate's capital structure. The causality relationship between these variables is generally an effect of the structure of corporate governance, as measured by indicators of board size, board composition, internal audit committee, and external audit committee on capital structure. Hasan and Butt's (2009) study found that board size and managerial share ownership had a significant and negative effect on capital structure, meaning that increased board size and managerial share ownership reduced capital structure, but the composition of the board and CEO / Chair duality had no significant and negative effect on structure capital. Based on these explanations, the research hypothesis formulated:

H2: Corporate governance has a significant effect on capital structure.

\subsection{The Effect of Corporate Governance on Corporate Values}

Agency Theory (Jensen and Meckling, 1976) explains that corporate governance has an important role to reduce agency costs and create long-term value for shareholders with a focus on board of commissioners' monitoring responsibilities and management functions that exist in senior executives (Rezaee (2007) Managerial opportunism hypothesis (Jensen, 1986) explains that managers may hold cash in the Corporate, and provide it to be used as additional income, used for personal welfare, and invest in projects that only increase personal prestige so that it is not beneficial to shareholders. Adi et al. (2013), Ghalandari (2013), Arifin et al. (2014), Yulianto (2014), Sukmono and Yadiati (2016) found that corporate governance has a significant and positive effect on Corporate value, meaning improvement (improvement) in corporate governance will increase the value of the Corporate formulated the beriktut research hypothesis:

H3: Corporate governance has a significant effect on Corporate value.

\subsection{The Effect of Profitability on Capital Structure}

Trade off theory (Modigliani and Miller, 1963) suggests that when a Corporate has high profitability, it must use more debt in order to obtain higher tax benefits for the use of debt. The research findings of Olderink (2013), Oppong-Boakye (2013), Sangeetha (2013), Kisaka (2015) found that profitability had a significant positive effect on capital structure. Pecking Order Theory (Myers and Majluf, 1984) says that when a Corporate needs capital, it first uses internal funds, then debt, and the last option is to issue new shares. Baskin (1989) suggests that using internal funds is better than relying on external capital, because internal funds are free of cost. Lots of empirical evidence such as the findings of Bevan and Danbolt (2002); Mazur (2007); Frank and Goyal, (2009); Anake et al (2014) found that profitability has a significant and negative effect on capital structure. The difference in empirical findings is a reason to re-examine the effect of profitability on capital structure, with the research hypothesis as follows:

H4: Profitability has a significant effect on capital structure.

\subsection{The Effect of Profitability on Corporate Values}

Irrelevance theory (Modigliani and Miller, 1958) explains that investment decisions and asset use activities determine performance that impacts on Corporate value, strengthens the cash flow signaling hypothesis and permanent earnings hypothesis (Lintner, 1956). High profitability has an impact on the Corporate's financial 
flexibility, so the Corporate is able to pay dividends to shareholders. The Corporate obtained a positive rating from the capital market, and stock prices increased. The Corporate's ability to generate profits, will determine the ability of funding to finance the Corporate's growth and dividend distribution for the owner. Ghosh and Arijit (2008) Adi et al. (2013), Asiri and Hameed (2014), Ekawati and Siswoyo (2015), Data et al. (2017) found financial performance with a high measure of profitability, had a significant and positive effect on Corporate value. The theoretical implication of the empirical study is that increasing profitability will increase the value of the Corporate. Based on these explanations, the research hypothesis formulated:

H5: Profitability has a significant effect on Corporate value.

\subsection{The Effect of Capital Structure on Corporate Values}

Irrelevant Theory (Modigliani and Miller, 1958) states that the capital structure does not affect the value of the Corporate. Trade off theory (Modigliani and Miller, 1963) predicts a positive correlation between capital structure and Corporate value with the assumption that tax benefits are greater than financial costs and agency costs, then the use of debt will have a positive impact on Corporate value (Barakat, 2014). However, the Pecking order theory (Myers and Majluf, 1984) explains that if companies want to use external funding sources, they must choose debt before new equity, because debt is cheaper and less sensitive to asymmetrical information, capital markets will react positively to debt issuance and prices shares rose. If the Corporate issues new shares, costs are higher and is very sensitive to asymmetrical information, the capital market will react negatively, and stock prices fall (Ogbulu and Emeni, 2012).

Leverage signaling theory (Ross, 1977) states that debt becomes a credible signal regarding the quality and prospects of the Corporate in the future, so that the market will react positively to the Corporate's stock price. Chowdhuri and Chowdhuri (2010) research; Ogbulu and Emeni (2012); Oluwabemiga (2013); Barakat (2014); Isaac (2014) found that the capital structure had a significant and positive effect on Corporate value, supporting trade-off theory, leverage signaling theory, and pecking order theory. The difference in empirical findings is a reason to re-examine the effect of capital structure on Corporate value, with the research hypothesis as follows:

H6: Capital structure has a significant effect on Corporate value.

The conceptual framework of this research was developed based on Agency Theory, capital structure theory within the corporate governance framework aims to increase profitability, optimal capital structure, and increase corporate value. Good corporate governance will affect profitability, capital structure, and Corporate value. This study will examine corporate governance within the framework of theoretical agencies capable of directing management to make managerial decisions that minimize agency problems and improve the welfare of shareholders. The conceptual framework of this research is as shown in Figure 1, as follows:

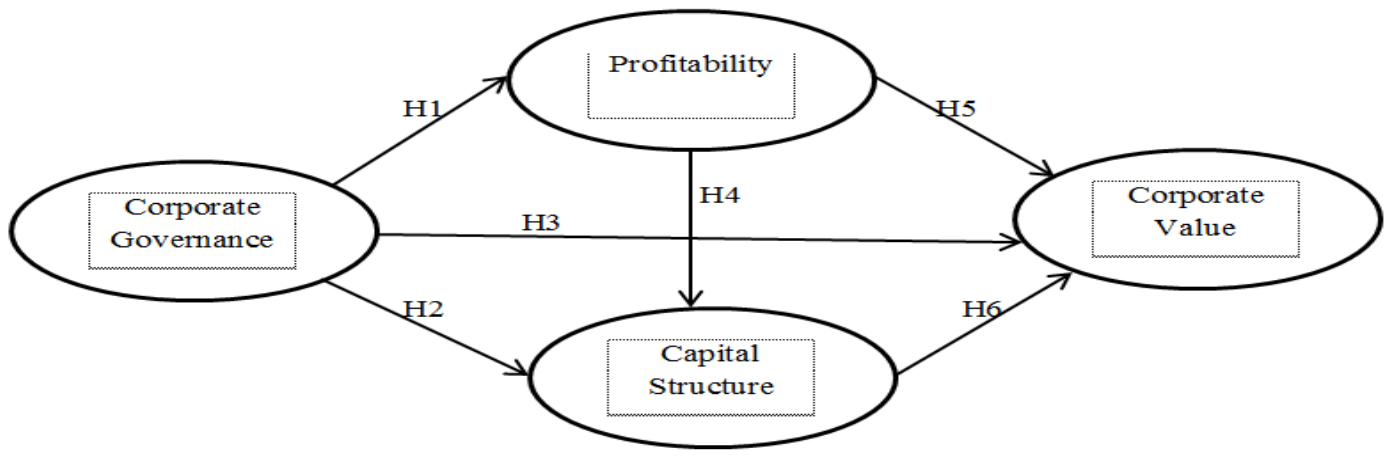

Figure 1. Research Concept Framework

Source: Developed for this study (Manu, 2018)

\section{Research Methods}

\subsection{Types of Research}

This type of research is explanatory research, namely research that explains the effect between variables, using secondary data. This research, aimed at explaining the effect between variables analyzed, and drawing conclusions that are useful for the development of science and used as a method of solving actual problems that occur in the field. This study focuses on empirical testing of the theory through testing the effect between variables and measurements and analysis techniques using statistical procedures testing hypotheses. The paradigm of this research is the positivistic paradigm, where conclusions from the results of research on the sample are seen to be generally applicable to the entire study population.

\subsection{Operational Definition of Research Variables}

This study consists of six variables, namely Corporate Governance, Profitability, Capital Structure, and Corporate 
Value. The research variables are grouped into two, namely exogenous variables and endogenous variables.

Corporate governance is a mechanism to reduce agency problems and become a means of control over the implementation of Corporate decisions by management based on managerial, investor and creditor interests. Corporate governance variables are measured by indicators of board size (BS), board composition, internal audit committee, external audit committee. Referring to the research of Yulianto et al. (2014). The Size of the Board of Commissioners (SBC) is the total of all members of the Corporate's Board of Commissioners.

An independent Board of Commissioners (IBC) is a board of commissioners of companies that are not members of management, majority shareholders, officials or in other ways that directly or indirectly affect the majority shareholders of companies that oversee the management of the Corporate. Referring to the research of Yulianto et al. (2014), the Independent Board of Commissioners is formulated as follows:

Independent Board of Commissioners $=\frac{\text { Independent Board of Commissioners }}{\text { Total Members of the Board of Commissioners }} \times 100 \%$

Members of the Audit Committee, consisting of members of the internal audit committee and members of the external audit committee. The Internal Audit Committee (IAC) is a member of the Audit Committee that comes from within the Corporate and is formed by Corporate management in order to improve the quality of financial accountability and improve Corporate performance. Referring to the research of Yulianto et al. (2014), the Internal Audit Committee (IAC), is formulated as follows:

Internal Audit Committee $=\frac{\text { Internal Audit Committee }}{\text { Total Audit Committee Members }} \times 100 \%$

The External Audit Committee (EAC) is a member of the Audit Committee originating from outside the Corporate and formed by Corporate management in order to improve the quality of financial accountability and improve Corporate performance. Referring to the research of Yulianto et al. (2014), the External Audit Committee (EAC), is formulated as follows:

Internal Audit Committee $=\frac{\text { External Audit Committe }}{\text { Total Audit Committee Members }} \times 100 \%$

\subsubsection{Endogenous Profitability Variables $\left(\mathrm{Y}_{2}\right)$}

Return on assets (ROA) is a comparison of after-tax profits with the total assets used in the Corporate's operations. ROA is an indicator that measures a Corporate's ability to generate asset returns. Referring to the study of Data et al. (2017), ROA is formulated as follows:

$$
\mathrm{ROA}=\frac{\text { Earing after tax }}{\text { Total Asset }} \times 100 \%
$$

Return on equity (ROE) is a comparison of post-tax profit with total equity used in the Corporate's operations. $\mathrm{ROE}$ is an indicator that measures a Corporate's ability to produce a return on equity. Referring to the study of Data et al. (2017), ROE is formulated as follows:

$\mathrm{ROE}=\frac{\text { Earing after tax }}{\text { Total Equity }} \times 100 \%$

Net profit margin (NPM) is a comparison of post-tax profits with total sales of the Corporate's net proceeds. NPM is an indicator that measures a Corporate's ability to generate the level of net income from each sales unit of the Corporate. Referring to the Barakat study (2014), and Data et al. (2017), ROE is formulated as follows:

$\mathrm{NPM}=\frac{\text { Earing after tax }}{\text { Net Sales }} \times 100 \%$

Gross Profit Margin (GPM) is a comparison of the total gross profit with the total net sales of the Corporate. GPM is an indicator that measures the ability of a Corporate to generate a level of gross profit from each unit sold by the Corporate. Referring to the Barakat study (2014), and Data et al. (2017), ROE is formulated as follows:

$\mathrm{GPM}=\frac{\text { Gross Profit Margin }}{\text { Net Sales }} \times 100 \%$ 


\subsubsection{Endogenous Variables Capital Structure (Y2)}

Capital structure is a combination of debt and equity in financing the assets and operations of the Corporate. Capital structure indicators are the ratio of total liabilities to total assets, ratio of total liabilities to total equity and ratio of total long-term liabilities to total equity. Debt to asset ratio is the comparison of total debt with total assets in financing the assets and operations of the Corporate. DAR indicator that measures the amount of debt in a Corporate's capital structure. Referring to Cekresi (2013), and Data et al. (2017), DAR is formulated as follows:

DAR $=\frac{\text { Total Debt }}{\text { Total Asset }} \times 100 \%$

Debt to equity ratio is the comparison of total debt with total equity in financing the assets and operations of the Corporate. DER indicator that measures the amount of equity in the Corporate's capital structure. Referring to Cekresi (2013), and Data et al. (2017), DER is formulated as follows:

$\mathrm{DER}=\frac{\text { Total Debt }}{\text { Total Equity }} \times 100 \%$

Long term debt to equity (LTDTE) is a comparison of total long-term debt with total equity in financing the assets and operations of the Corporate. LTDTE indicators that measure the amount of equity in the Corporate's capital structure. Referring to Data et al. (2017), LTDTE is formulated as follows:

LTDTE $=\frac{\text { Long Term Debt }}{\text { Total Equity }} \times 100 \%$

Corporate values are book value and stock market value. Indicators of Corporate values are: Closing Price (CP), Price to Book value (PBV), and Tobin's Q. Closing Price is the price of shares in the capital market at the close of trading activities. Referring to the research of Yulianto et al. (2014), Data et al. (2017). Price to Book value (PBV) is the ratio of the stock market to the book value of the stock, which shows the value of the Corporate according to the capital market valuation at a certain time. Referring to the research of Adi et al. (2013) and Data et al. (2017), PBV is calculated by the following formula:

Price to Book Value $=\frac{\text { Stock Market Price }}{\text { Book Value of Stock }}$

The market price reflects the expected price of the investor, if the investor's expectation of one type of stock is high, then the demand for the stock is also high so the price in the market is also relatively high, the market price can also be lower than the book value, therefore try using Tobin's approach q to measure Corporate value. Tobin's $\mathrm{q}$ is the market value of the equity plus the total debt of the Corporate divided by the total assets. Referring to the research of Adi et al. (2013), dan Data et al. (2017), Tobin's q is calculated by the following formula:

Tobin, s Q $=\frac{\text { Market Value of Equty }+ \text { Total Long Term Debt }}{\text { Total Asset }}$

\subsection{Population and Sample}

Companies are listed on the Indonesia Stock Exchange. The population in this study is an all manufacturing industry companies in Indonesia Stock Exchange (IDX), with observation period from 2012 to 2017 amounted to 84 companies. Sampling using a purposive method is the researcher determines the specific criteria or goals for the sample to be studied (Indriantoro and Supomo 1999: 146). The study is limited for the period 2012 to 2017. The unit of analysis using data from 25 corporates is multiplied by 6 years is 150 financial statements. Pooling time series and cross-section data. Companies that meet the criteria for sampling are as shown in Table 1, as follows: 
Table 1. List of Corporate Name Research Samples

\begin{tabular}{|l|l|l|}
\hline No. & Corporate Code & Corporate Name \\
\hline 1 & AMFG & AsahimasFiat Glass Tbk \\
\hline 2 & ARNA & Arwana Citra Mulia Tbk \\
\hline 3 & AKPI & Argha Karya Prima Industri Tbk \\
\hline 4 & AISA & Tiga Pilar Sejahtra Food Tbk \\
\hline 5 & DLTA & Delta Jakarta Tbk \\
\hline 6 & DVLA & Darya-Varia Laboratoria Tbk \\
\hline 7 & GGRM & Gudang Garam Tbk \\
\hline 8 & HMSP & HM Sampoerna Tbk \\
\hline 9 & INDF & Indofood Sukses Makmur Tbk \\
\hline 10 & INTP & Indocement Tunggal Prakarsa Tbk \\
\hline 11 & IPOL & Indopoly Swakarsa Industri Tbk \\
\hline 12 & KAEF & Kimia Farma Tbk \\
\hline 13 & KIAS & Keramika Indonesia Assosiasi Tbk \\
\hline 14 & KLBF & Kalbe Farma Tbk \\
\hline 15 & MERK & Merk Tbk \\
\hline 16 & MLBI & Multi Bintang Indonesia Tbk \\
\hline 17 & MYOR & Mayora Indah Tbk \\
\hline 18 & ROTI & Nipon IndosariCorporindo Tbk \\
\hline 19 & SKLT & Sekar Laut Tbk \\
\hline 20 & SMCB & Hotcim Indonesia Tbk \\
\hline 21 & TCID & Mandom Indonesia Tbk \\
\hline 22 & TKIM & Pabrik Kertas Ciwi Kimia Tbk \\
\hline 23 & TOTO & Surya Toto Indonesia \\
\hline 24 & TSPC & Tempo Scan Pacific Tbk \\
\hline 25 & UNVR & Unilever Indonesia Tbk \\
\hline
\end{tabular}

Source: Indoneisa Stock Exchange on the site http://www.idx.co.id Corporate financial report (2018)

\subsection{Data Collection Method}

The data collection method used in this study is the documentation method. The documents that will be used in this study are audited financial statements by public accountants and annual reports, Corporate financial performance profiles, and fact book for Indonesian stock exchanges in 2012-2017. The type of data used in this study is secondary data in the form of financial report documents and Corporate annual reports, the data source used is the Indonesia Stock Exchange through the site http://www.idx.co.id.

\subsection{Data Analysis Methods}

\subsubsection{Analysis of Descriptive Statistics}

Data that has been collected is analyzed by the ratio and tabulated, each calculated the minimum value, the maximum value, and the average of each research indicator. The purpose of description analysis is to describe the development trends of each research indicator, without intending to make generalizations.

\subsubsection{Analysis of Infrential Statistics}

Inferential statistical analysis of this study uses structural equation models with the Generalized Structured Component Analysis (GSCA) approach. The approach (GSCA) is varince based or component based, is a predictive model (prediction analysis), and can be used to conCorporate the theory with empirical data. The bootstrapping resampling method uses the GeSCA software which can be accessed at www.sem-gesca.org. The assumption in using GSCA analysis is linearity, meaning that the correlation between latent variables must be linear. Data to be analyzed with GSCA must be tested for linearity. Linearity test using the SPSS version 22 program, the test results are as follows: 
Table 2. Linearity Test Results

\begin{tabular}{|l|l|c|c|c|}
\hline \multicolumn{2}{|c|}{ Correlation } & \multirow{2}{*}{ F } & \multirow{2}{*}{ Probabilitas } & Information \\
\cline { 1 - 2 } Exogenous Variable & Endogenous variable & & & Linear \\
\hline Corporate Governance $(\mathrm{X})$ & Profitability $\left(\mathrm{Y}_{1}\right)$ & 5,687 & 0.018 & Linear \\
\hline Corporate Governance $(\mathrm{X})$ & Capital Structure $\left(\mathrm{Y}_{2}\right)$ & 2,178 & 0.143 & Linear \\
\hline Corporate Governance $(\mathrm{X})$ & Corporate values $\left(\mathrm{Y}_{3}\right)$ & 0.964 & 0.328 & Linear \\
\hline Profitability $\left(\mathrm{Y}_{1}\right)$ & Capital Structure $\left(\mathrm{Y}_{2}\right)$ & 1,180 & 0.280 & Linear \\
\hline Profitability $\left(\mathrm{Y}_{1}\right)$ & Corporate value $\left(\mathrm{Y}_{3}\right)$ & 340,745 & 0.000 & Linear \\
\hline Capital Structure $\left(\mathrm{Y}_{2}\right)$ & Corporate value $\left(\mathrm{Y}_{3}\right)$ & 14,880 & 0.000 & \\
\hline
\end{tabular}

Source: Secondary Data Processed in 2018

\section{Research Findings}

\subsection{Description of Research Variables and Indicators}

Descriptive statistical analysis aims to describe data that has been collected as it is without intending to take general conclusions or generalizations. The data described is in the form of a minimum value, the maximum value, the average of each indicator forming latent variables, as listed in table 3, below:

Table 3. Description of Research Variable Value Indicators

\begin{tabular}{|c|c|c|c|c|c|c|c|c|c|c|}
\hline \multirow[t]{2}{*}{ No } & \multirow[t]{2}{*}{ Indikator Variabel } & \multicolumn{6}{|c|}{ Average Per Year } & \multicolumn{3}{|c|}{ Average 6 Years } \\
\hline & & 2012 & 2013 & 2014 & 2015 & 2016 & 2017 & Min & Max & Mean \\
\hline \multirow[t]{5}{*}{1} & \multicolumn{3}{|c|}{ Corporate Governance $(\mathrm{X})$} & & & & & & & \\
\hline & SBC & 5 & 5 & 5 & 5 & 5 & 5 & 3 & 8 & 5 \\
\hline & IBC & 2 & 2 & 2 & 2 & 2 & 2 & 1 & 4 & 2 \\
\hline & IAC & 2 & 2 & 2 & 2 & 2 & 2 & 2 & 3 & 2 \\
\hline & EAC & 1 & 1 & 1 & 1 & 1 & 1 & 1 & 2 & 1 \\
\hline \multirow[t]{5}{*}{2} & \multicolumn{3}{|c|}{ Profitabilitas (Y2) } & & & & & & & \\
\hline & ROA ( persen) & 14,88 & 16,58 & 13,29 & 11,69 & 10,88 & 9,38 & $-13,58$ & 71,51 & 12,78 \\
\hline & ROE ( persen) & 28,57 & 27,38 & 26,91 & 20,39 & 21,48 & 17,23 & $-24,9$ & 143,5 & 23,66 \\
\hline & NPM ( persen) & 12,63 & 12,95 & 12,21 & 10,41 & 9,68 & 8,20 & $-29,23$ & 39,44 & 11,01 \\
\hline & GPM ( persen) & 33,35 & 33,52 & 32,83 & 31,52 & 32,37 & 30,17 & $-6,04$ & 73,88 & 32,29 \\
\hline \multirow[t]{4}{*}{3} & \multicolumn{3}{|c|}{ Struktur Modal ( $\left.\mathbf{Y}_{2}\right)$} & & & & & & & \\
\hline & DAR ( persen) & 39,16 & 41,36 & 40,16 & 40 & 39,92 & 40,72 & 8 & 121 & 40,22 \\
\hline & DER ( persen) & 83,84 & 78,8 & 81,84 & 83,88 & 113,84 & 84,92 & 9 & 303 & 87,85 \\
\hline & $\begin{array}{l}\text { LTDTE } \\
\text { ( persen) }\end{array}$ & 25,88 & 26,96 & 31 & 33,76 & 33,04 & 32,72 & 2 & 179 & 30,56 \\
\hline 4 & \multicolumn{3}{|c|}{ Nilai Perusahaan $\left(\mathbf{Y}_{4}\right)$} & & & & & & & \\
\hline & $\mathrm{CP}(\mathrm{Rp})$ & 18.498 & 10.463 & 11.790 & 12.175 & 7.708 & 9.796 & 72 & 152.000 & 11.766 \\
\hline & $\operatorname{PBV}(\mathrm{x})$ & 7,40 & 6,63 & 7,93 & 6,09 & 6,94 & 7,41 & 0,12 & 82,44 & 7,07 \\
\hline & $\mathrm{Q}(\mathrm{x})$ & 3,98 & 4,77 & 4,53 & 4,70 & 4,24 & 4,33 & 0,21 & 29,79 & 4,43 \\
\hline
\end{tabular}

Data source: Corporate financial report, fact book Idx situs http://www.idx.co.id data processed in 2018

\subsection{Statistical Analysis with GSCA}

The overall Fit Model Test shows that the FIT value of 0.549 means that the dependent latent variable can be explained by independent latent variables in the structural model of 54.9 percent or in other words the information contained in the data can be explained by 54.9 percent by the model, while the remaining 45.1 percent is explained by other variables that have not been included in the research model and errors.

Considering the variables in the model more than one independent latent will affect the dependent latent variable, it is more appropriate if the interpretation of the accuracy of the model uses a corrected FIT value (AFIT). The AFIT value of 0.547 means that the dependent latent variable can be explained by the independent latent variable in the model at 54.7 percent or in other words the information contained in the data can be explained by 54.7 percent by the model, while the remaining 45.3 percent is explained by other variables that have not been included in the research model and errors.

\subsubsection{Outer Model Testing Results}

Outer model (Measurement Model) that describes the relationship between latent variables with indicators or manifest variables (measurement model). Based on the conceptual framework and model, the outer model is then developed which is often referred to as the outer relation that defines how each indicator block is related to its latent variables, the test results obtained with GSCA Bootstrapping calculations. Detailed test results as in table 4, as follows: 
Table 3. Measurement Model Test Results (Outer Model)

\begin{tabular}{|c|c|c|c|c|}
\hline \multirow[t]{2}{*}{ Indicator } & \multicolumn{3}{|c|}{ Weight } & \multirow[t]{2}{*}{ Information } \\
\hline & Estimate & SE & CR & \\
\hline \multicolumn{4}{|c|}{ Measurement Model of Corporate Governance Variables (X) } & \\
\hline Size of the Board of Commissioners (SBC) & 0.867 & 0.038 & $22.82 *$ & Significant \\
\hline Independent Board of Commissioners (IBC) & 0.295 & 0.212 & 1.39 & Not Significant \\
\hline Internal Audit Committee (IAC) & 0.919 & 0.021 & $43.76^{*}$ & Significant \\
\hline External Audit Committee (EAC) & -0.461 & 0.051 & $9.04 *$ & Significant \\
\hline \multicolumn{4}{|c|}{ Measurement Model of Profitability Variable (Y1) } & \\
\hline Return on asset (ROA) & 0.154 & 0.097 & 1.59 & Not Significant \\
\hline Return on equity (ROE) & 0.428 & 0.077 & $5.56^{*}$ & Significant \\
\hline Net profit margin (NPM) & 0.159 & 0.072 & $2.21 *$ & Significant \\
\hline Gross profit margin (GPM) & 0.559 & 0.072 & $7.76^{*}$ & Significant \\
\hline \multicolumn{5}{|c|}{ Measurement Model of Capital Structure Variable (Y2) } \\
\hline Debt to assets ratio (DAR) & 0.917 & 0.011 & $83.36^{*}$ & Significant \\
\hline Debt to equity ratio (DER) & 0.889 & 0.032 & $27.78^{*}$ & Significant \\
\hline Long term debt to equity (LTDTE) & 0.810 & 0.020 & $40.50 *$ & Significant \\
\hline \multicolumn{4}{|c|}{ Measurement Model of Corporate Value Variable (Y3) } & \\
\hline Closing price $(\mathrm{CP})$ & 0.423 & 0.180 & $2.35^{*}$ & Significant \\
\hline Price to book value (PBV) & 0.491 & 0.053 & $9.26^{*}$ & Significant \\
\hline Tobin's q (Q) & 0.357 & 0.060 & $5.95 *$ & Significant \\
\hline \multicolumn{5}{|c|}{$\mathrm{CR}^{*}=$ Sgnificant at 0.05 level } \\
\hline \multicolumn{5}{|c|}{ Source: GSCA analysis results are processed in 2018.} \\
\hline
\end{tabular}

The value of the outer weight and outer weight shows the weight of the value of each indicator as a measure of each latent variable. The indicator with the largest outer weight and outer weight indicates that the indicator is the measure of the strongest or dominant variable. The results of the outer weight and outer weight indicators of the seven latent variables measured were obtained through GSCA Bootstrap calculations which also produced the value of the critical ratio (CR) which is similar to the value of statistical $t$, if the weight value is above 0.4 and the CR value is greater than $1,96 \mathrm{~T}$ tables, it was decided significantly.

\subsubsection{Inner Model Testing Results}

The results of the inner model test (structural model) explain the relationship between latent variables that describe the relationship between independent latent variables and dependent latent variables based on substantive theory that defines the relationship of each independent latent variable to the dependent latent variable. The effect path coefficient values between independent latent variables on the dependent latent variables, obtained through the calculation of Generalized Structured Compoment Analysis (GSCA) and significant tests obtained through Bootstrapping which also found the value of the critical ratio (CR) equivalent to $\mathrm{T}$. Testing the inner model (structural model) essentially testing the hypothesis in the study. Hypothesis testing is done by the T test on each connecting path that effects between latent variables. Based on the results of the GSCA analysis, the hypothesis model was tested, as in table 4, as follows:

Table 4. Structural Model test results (Inner Model)

\begin{tabular}{|l|c|c|c|c|c|c|}
\hline \multirow{2}{*}{ Hypothesis } & \multirow{2}{*}{ Path } & Path Coeficients & \multicolumn{2}{|l|}{} \\
\cline { 3 - 7 } & & Estimate & SE & CR (T) & \multicolumn{2}{|c|}{ Information } \\
\hline H1 & $\mathrm{X} \rightarrow \mathrm{Y} 1$ & 0.721 & 0.059 & $12.22^{*}$ & Significant & H1 Accepted \\
\hline H2 & $\mathrm{X} \rightarrow \mathrm{Y} 2$ & 0.496 & 0.090 & $5.51^{*}$ & Significant & H2 Accepted \\
\hline H3 & $\mathrm{X} \rightarrow \mathrm{Y} 3$ & 0.810 & 0.052 & $15.58^{*}$ & Significant & H3 Accepted \\
\hline H4 & Y1 $\rightarrow$ Y2 & 0.694 & 0.080 & $8.68^{*}$ & Significant & H4 Accepted \\
\hline H5 & Y1 $\rightarrow$ Y3 & 0.905 & 0.030 & $30.17^{*}$ & Significant & H5 Accepted \\
\hline H6 & Y2 $\rightarrow$ Y3 & 0.554 & 0.070 & $7.91^{*}$ & Significant & H6 Accepted \\
\hline CR* = Significant at 0,05 level
\end{tabular}

Source: GSCA analysis results are processed in 2018.

\section{Discusion}

\subsection{The Effects of Corporate Governance on Profitability}

Corporate governance $(\mathrm{X})$ has a significant effect on profitability (Y1). Positive path coefficient value $0.721, \mathrm{CR}$ value $12.22 *$ is greater than 1.96 ; significant at the level of $\mathrm{P}=0.05$. The path coefficient value is 0.721 , meaning that profitability is determined by corporate governance of $72.1 \%$, while the remaining $27.9 \%$ is determined by other variables and errors. The test results accepting hypothesis 1 means that the effect of corporate governance 
on profitability is that corporate governance improvements can increase profitability. The findings of this study support the results of the research by Mathur and Gill (2011), Adi et al. (2013), Danoshana and Ravivathani (2013), Yulianto (2014) and Yemane (2015) who found corporate governance had a positive and significant effect on profitability. does not support the findings of Coleman's research and Biekpe (2006) and Arifin (2014) who found corporate governance had a negative and significant effect on profitability.

\subsection{The Effects of Corporate Governance on Capital Structure}

Corporate governance $(\mathrm{X})$ has a significant effect on capital structure (Y2). Path coefficient value 0.496; CR value $5.51^{*}$ greater than 1.96; at the level of $\mathrm{P}=0.05$ (table 4 ). The path coefficient value is 0.496 , meaning that the capital structure is determined by corporate governance by $49.6 \%$, while the remaining $50.4 \%$ is determined by other variables and errors. The test results support to accept the hypothesis 2 . It means that the improvement or improvement of corporate governance will improve the capital structure. The effect of corporate governance on the capital structure is that corporate governance improvements will increase the use of debt to the optimum limit in the capital structure. The results of this study support the research of Yulianto (2014), agreeing with Donaldson 1961; Myers 1984; in Myers and Majluf, 1984. Not supporting the research findings of Hasan and Butt (2009), Kargar et al. (2014).

\subsection{The Effect of Corporate Governance on Corporate Values}

Corporate Governance (X) has a significant effect on Corporate value (Y3). Path coefficient value 0.810; CR value $15.58 *$ greater than 1.96; at level $\mathrm{p}=0.05$ (table 4 ). The path coefficient value is 0.810 , meaning that the value of the Corporate is determined by corporate governance at $81.0 \%$, while the remaining $19.0 \%$ is determined by other variables and errors. The test results support to accept hypothesis 3. It means that improvements in corporate governance will increase the value of the Corporate. Supporting the research of Adi et al. (2013), Ghalandari (2013), Arifin et al. (2014), Yulianto (2014), Sukmono and Yadiati (2016) who found that corporate governance had a significant and positive effect on Corporate value.

\subsection{The Effect of Profitability on Capital Structure}

Profitability (Y1) has a significant positive effect on capital structure (Y2). The path coefficient value is 0.694 , the value of $\mathrm{CR}$ is $8.68 *$ greater than 1.96; at the level of $\mathrm{P}=0.05$ (table 4). The path coefficient value is 0.694 , meaning that the capital structure is determined by profitability of $69.4 \%$, while the remaining $30.6 \%$ is determined by other variables and errors. The test results support the acceptance of hypothesis 4 . Means that the increase in profitability will improve the capital structure. The findings of this study support the findings of Oolderink (2013), Oppong-Boakye (2013), Sangeetha (2013), Kisaka (2015), consistent with trade off theory (Modigliani and Miller, 1963). The findings of this study do not support Pecking Order Theory ( Myers and Majluf, 1984) and also do not support the research findings of Frank and Goyal (2009), Anake et al. (2014) who found profitability had a significant negative effect on Capital Structure.

\subsection{The Effect of Profitability on Corporate Values}

Profitability (Y1) has a significant positive effect on Corporate value (Y3). Path coefficient value 0.905; the value of CR 30.17* is greater than 1.96; at the level of $\mathrm{P}=0.05$ (table 4). Path coefficient value 0.905 , meaning that the value of the Corporate is determined by profitability of $90.5 \%$, while the remaining $9.5 \%$ is determined by other variables and errors. The test results support to accept the hypothesis 5 . Means that the increase in profitability will increase the value of the Corporate. The findings of this study support the research findings of Ghosh and Alijit (2008), Adi et al. (2013), Yulianto (2014), Asiri and Hameed (2014), Ekawati and Siswoyo (2015), Data et al. (2017). Supporting signaling theory (Ross, 1977), Cash flow signaling hypothesis and permanent earnings hypothesis (Lintner, 1956); (Marsh and Merton, 1987), Irrelevance theory (Modigliani and Miller, 1958), reinforcing the cash flow signaling hypothesis and permanent earnings hypothesis (Lintner, 1956).

\subsection{The Effect of Capital Structure on Corporate Values}

Capital structure (Y2) has a significant positive effect on Corporate value (Y3), path coefficient value 0.554; the value of $\mathrm{CR} 7.91^{*}$ is greater than 1.96; at the level of $\mathrm{P}=0.05$ (table 4). The path coefficient value is 0.554 , meaning that the value of the Corporate is determined by the capital structure of $55.4 \%$, while the remaining $44.6 \%$ is determined by other variables and errors. The test results accept hypothesis 6 . It means that the increase in debt in the capital structure to a certain extent will increase the value of the Corporate. The findings of this study support trade off theory (Modigliani and Miller, 1963), leverage signaling theory (Ross (1977), pecking order theory (Myers and Majluf, 1984), and research findings by Chowdhuri and Chowdhuri (2010), Ogbulu and Emeni (2012), Ogbulu and Emeni (2012); Oluwabemiga (2013); Barakat (2014); Isaac (2014); Data et al. (2017). The findings of this study do not support the research of Ghalandari (2013), Adi et al. (2013) who find the capital structure has a significant negative effect on Corporate value, which means an increase in capital structure will reduce the value 
of the Corporate.

\subsection{Limitations of Research}

1) The limitations of this study occur because there are other variables that have not been included in the research model, so that not all information can be disclosed by data collected and analyzed.

2) This study only uses financial report data which is historical data or past data (secondary data), if there is a disclosure error in the financial statements, it also effects the results of the analysis and conclusions.

3) The assumption in this study is that all Basic Industry Manufacture companies are considered to have the same characteristics because they use the same accounting standards in preparing financial statements, so that ignoring differences in one type of industry with another can cause bias from the data used in this study effectd the results of the analysis.

\section{Conclusion}

The effect of corporate governance on profitability is the improvement of corporate governance will increase profitability. Proof with empirical data statistically shows a positive and significant path coefficient. Theoretical implications of increasing or improving corporate governance will increase profitability.

The effect of corporate governance on capital structure is that improvements in corporate governance will result in an increase in capital structure. Proof with empirical data statistically shows a positive and significant path coefficient. Theoretical implications of improving or improving corporate governance will improve the capital structure.

The effect of corporate governance on Corporate value can be interpreted that improvements in corporate governance will result in an increase in the value of the Corporate. Proof with empirical data statistically shows a positive and significant path coefficient. The theoretical implication is that increasing or improving corporate governance will increase the value of the Corporate.

The effect of profitability on capital structure is an increase in profitability will increase the capital structure. Proof with empirical data statistically shows a positive and significant path coefficient. The theoretical implication is that increasing the ability to generate profits will increase the capital structure.

The effect of profitability on the value of the Corporate is an increase in profitability will increase the value of the Corporate. Proof with empirical data statistically shows a positive and significant path coefficient. The theoretical implication is that increasing the ability to generate profits will increase the value of the Corporate.

The effect of the capital structure on the value of the Corporate is an increase in the capital structure until the optimal level will increase the value of the Corporate. Proof with empirical data statistically shows a positive and significant path coefficient. The theoretical implication is that increasing dividend policy will increase the value of the Corporate.

\section{Recommendations}

7.1 Recommendations for Advanced Research

1) Future research can add other variables that have not been included in this research model, to obtain a more comprehensive research model.

2) Using financial report data and other relevant information to overcome the limitations of historical data in financial statements.

3) Further research can be done elsewhere in a longer time, or replace other research objects.

\subsection{Recommendations for Companies}

1) Corporate governance improvements should be directed at a balance of increasing Corporate growth and increasing value for shareholders. Improving Corporate Governance that will consistently improve profitability, capital structure, and corporate value will lead to increased prosperity of all parties related to the Corporate.

2) Using debt at a low cost level so as not to burden the Corporate with high interest costs and the risk of failure.

3) Maintaining and increasing profitability is a good decision, because profitability is a very strong variable in determining the value of the Corporate. Investors will appreciate the shares of companies that have high financial performance at the highest prices.

4) Must use financial data along with other relevant information for the purpose of analysis to produce more precise predictions. Using other economic information to overcome the limitations of financial statements, because financial report data is historical data or past data. If there are errors in disclosures in the financial statements, the prediction results will be less precise.

\section{References}

Adi, Tri Wahyu. Suhadak. Siti Ragil Handayani, Sri Mangesti Rahayu (2013). The Influence of corporate governance and capital structure on risk, financial performance and Corporate value: a study on the mining 
Corporate listed in Indonesia stock exchange in 2009-2012. European Journal of Business and Management, 5 (29): 200-217

Anake, Atseye Fidelis. Obim, Edim Ndifon and Eke, Felix Awara. (2014). Determinants of financial structure: Evidence from Nigerian quoted Corporates, Research Journal of Finance and Accounting, 5 (16): 53-66.

Arifin, Jauhar., Suhadak., Siti, Endang Astuti and Arifin, Zainul. (2014).The influence of corporate governance, intellectual capital on financial performance and Corporate value of bank sub-sector companies listed at Indonesia stock exchange in period 2008-2012. European Journal of Business and Management, 6 (26): 159167.

Asiri, Batool K. and Hameed, Salwa A. (2014). Financial ratios and Corporate's value in the Bahrain bourse. Research Journal of Finance and Accounting, 5 (7): 1-9.

Barakat, Abdallah. (2014). The impact of financial structure, financial leverage and profitability on industrial companies shares value (applied study on a sample of Saudi industrial companies). Research Journal of Finance and Accounting, 5 (1): 55-66.

Baskin, J. (1989). An empirical investigation of the pecking order hypothesis. Financial Management, 19 (1): $26-$ 35.

Bevan, A.A. and Danbolt, J. (2002). Capital structure and its determinants in the United Kingdom - a decompositional analysis. Applied Financial. Economics, 12 (3): 159-170.

Çekrezi, Anila. (2013). Impact of Corporate specific factors on capital structure decision: An empirical study of Albanian Corporates. European Journal of Sustainable Development, 2 (4). 135-148.

Data, Ari. Alhabsji, Taher., Rahayu, Sri Mangesti., Handayani, Siti Ragil. (2017). Effect of growth, liquidity, business risk and asset usage activity, toward capital structure, financial performance and corporate value (study at manufacturing companies listed in Indonesia Stock Exchange In 2010-2015). European Journal of Business and Management, 9 (24): 9-25.

Ekawati, Gresylia Gresylia and Siswoyo, Bambang Banu. (2015). The effects of current ratio and debt to equity ratio on dividend policy through net profit margin (a study on manufacturing companies listed in indonesia stock exchange in the period of 2013). Research Journal of Finance and Accounting, 6 (24): 31-37.

Frank, Murray and Goyal, Vidhan. (2009). Capital structure decisions: which factors are reliably important?. Financial Management, 38 (1): 1-37.

Ghalandari, Kamal. (2013). The moderating effects of growth opportunities on the relationship between capital structure and dividend policy and ownership structure with Corporate value in Iran: Case study of Tehran Securities exchange. Research Journal of Applied Sciences, Engineering and Technology, 5 (4): 1424-1431.

Ghosh and Arijit. (2008). Do leverage, dividen policy, profitability influence future value of Corporate? Evidence from India.

Gill, Amarjit, dan John Obradovich. 2012. "The Impact of Corporate Governance and Financial Leverage on the Value of American Corporates". Dalam International Research Journal of Finance and Economics,. Volume 91 Hal 1 - 11. Amerika Serikat : Liberty University.

Hanafi, Mamduh. M. (2010). Financial Management. First Edition of Faculty of Economics University Yogyakarta.

Hasan, A. and Butt, S.A. (2009). Impact of ownership structure and corporate governance on capital structure of Pakistani listed companies. International journal and management, 4 (2): 50-57.

Indriantoro, Nur dan Supomo, Bambang. (1999). Business Research Methodology. BPFE-Yogyakarta.

Isaac, Lambe. (2014). Corporate capital structure and Corporate's market value in Nigeria. Research Journal of Finance and Accounting, 5 (12): 16-31.

Jensen, Michael C. and Meckling, William H. (1976). Theory of the Corporate: managerial behavior, agency costs and ownership structure. Journal of Financial Ecomics, 3 (4): 305-360.

Jensen, M.C. (1986). Agency costs of free-cash-flow, corporate finance, and takeovers. American Economic Review, 76(2): 323-329.

Keown, Arthur J. Scott, David F, Jr.Martin John D. Petty, J. William, Interpretation by Djakman, Chaerul D. Fundamentals of Financial Management. (1999). Salemba Empat. Jakarta. Simon and Schuster (Asia) Pte.Ltd.Prentice-Hall Inc.

Kisaka, Sifunjo E., Hillary Kipngetich Kitur, and Aloise Mbithi. (2015). The relationship between profits and dividend payout of commercial banks in Kenya. Research Journal of Finance and Accounting, 6 (10): 173 185.

Lintner, John. (1956). Distribution of incomes of corporations among dividens, retained earnings, and taxes. Papers and Proceedings of the Sixty-eighth. Annual Meeting of the American Ecomic Association. The American Ecomic Review, 46 (2): 97-113.

Modigliani, Franco, and Miller, Merton H. (1958). The cost of capital, corporate finance and the theory of investment. American Economic Review, 48 (48): 261-297.

Modigliani, Franco, and Miller, Merton H. (1963). Corporate income taxes and the cost of capital: a correction. 
American Economic Review, 53 (3): 433-443.

Myers, S. C. and Majluf, N. S. (1984). Corporate financing and investment decisions when Corporates have information that investors don't have. Journal of Financial Ecomics, 13 (2): 187-222.

Nasution, Marihot dan Setiawan, Doddy. (2007). Pengaruh Corporat Governance Terhadap Manajemen Laba di Industri Manufaktur.SNA X, Makassar, 26-28 Juli 2007.

Ogbulu, Onyemachi Maxwell and Emeni, Francis Kehinde. (2012). Capital structure and Corporate value: empirical evidence from Nigeria. International Journal of Business and Social Scienc, 3 (19): 252-261.

Oluwagbemiga, Oyerogba Ezekiel. (2013). Perceived relationship between corporate capital structure and Corporate value in the Kenyan listed companies. Research Journal of Finance and Accounting, 4 (19): $157-$ 165.

Oolderink, Pim. (2013). Determinants of capital structure: static trade-off theory vs. pecking-order theory: evidence from Dutch listed Corporates. University of Twente P.O. Box 217, 7500AE Enschede The Netherlands. Pp. 1-9. p.j.oolderink@student.utwente.nl

Oppong-Boakye, Paul Kofi. Appiah, Kingsley Opoku. Afolabi,James Konadu. (2013). Determinants of capital structure: evidence from Ghanaian Corporates. Research Journal of Finance and Accounting, 4 (4): 44-52.

Rezaee, Z. (2007). Corporate governance post-sarbanes oxley: regulations, requirements and integrated processes. John Willey \& Sons, Inc.

Ross, Stephen A. (1977). The determination of financial structure: the incentive signaling approach. Bell Journal of Economics 8 (1): 23-40.

Sangeetha, M. Sivathaasan, N. (2013). Factors determining capital structure: a case study of listed companies in Sri Lanka. Research Journal of Finance and Accounting, 4 (6): 236-247.

Sukmono, Sigit and Yadiati, Winwin. (2016). effect of board of commissionersand audit committee on the Corporate value with mediating effect financial reporting quality. Research Journal of Finance and Accounting, 7 (2): 131-148.

Todorović, "Impact of Corporate Governance on Performance of Companies," Montenegrin Journal of Economics, vol. 9, pp. 47- 53, 2013.

Yulianto, Arief ., Suhadak., Darminto. and Siti Ragil Handayani. (2014). The role of corporate governance, dividend policy, and capital structure on ownership structure toward the Corporate value. European Journal of Business and Management, 6 (8): 134-141.

Yemane, Abreham Amanuel., Raju, R. Madhusudana., and Raju, M. Lakshmipathi. (2015). The impact of corporate governance on Corporate's performance: evidence from ethiopian insurance companies. Research Journal of Finance and Accounting, 6 (9): 225-233. 